Fall 1998

\title{
Harmonization and the Goals of Copyright: Property Rights or Cultural Progress?
}

Kenneth D. Crews

Indiana University School of Law, Indianapolis

Follow this and additional works at: https://www.repository.law.indiana.edu/ijgls

Part of the Intellectual Property Law Commons, and the International Law Commons

\section{Recommended Citation}

Crews, Kenneth D. (1998) "Harmonization and the Goals of Copyright: Property Rights or Cultural Progress?," Indiana Journal of Global Legal Studies: Vol. 6 : Iss. 1 , Article 4.

Available at: https://www.repository.law.indiana.edu/ijgls/vol6/iss1/4

This Symposium is brought to you for free and open access by the Law School Journals at Digital Repository @ Maurer Law. It has been accepted for inclusion in Indiana Journal of Global Legal Studies by an authorized editor of Digital Repository @ Maurer Law. For more information, please contact rvaughan@indiana.edu.

\section{$\Psi$}

JEROME HALL LAW LIBRARY

INDIANA UNIVERSITY

Maurer School of Law
Bloomington 


\title{
Harmonization and the Goals of Copyright: Property Rights or Cultural Progress?
}

\author{
KENNETH D. CREWS*
}

\section{INTRODUCTION}

\begin{abstract}
A leading force shaping United States copyright law in recent decades has been the desire to conform U.S. law to the laws of other countries where many American companies and individuals in the copyright industries frequently pursue business.' Those countries are often in Western Europe, where U.S. publishers, film producers, software developers, and others regularly make sales. One may look to trends and developments in other countries to see the future of U.S. copyright. The "harmonization" of laws has brought the promise of predictability and ease of conducting business across national borders. ${ }^{2}$
\end{abstract}

* Kenneth D. Crews (B.A., Northwestern University; J.D., Washington University; Ph. D., University of California, Los Angeles) is an Associate Professor in the Indiana University School of Law-Indianapolis and the IU School of Library and Information Science. He is also Associate Dean of the Faculties for Copyright Management. Email address: kcrews@indiana.edu. Copyright 1998, Kenneth D. Crews. The author would like to thank his colleague at Indiana University, Professor Fred Cate, for inviting him to join the roundtable on "Sovereignty and the Globalization of Intellectual Property." He is especially grateful to the other participants who commented on this paper and gave many valuable insights, including Jerome Reichman of Vanderbilt University, Trotter Hardy of the College of William and Mary, Keith Aoki of the University of Oregon, and Marshall Leaffer of Indiana University. Bringing this paper to its final, published form has required yet other important support. Becky Parman, assistant in the IU Copyright Management Center, deployed her word-processing skills to produce the early drafts, and Dwayne Buttler, one of the author's law students who now works in the Center, read the manuscript while in progress and provided important comments. Jennifer Garrett and the other editors of this Journal exhibited endless patience and care as they brought this work to publication. Much of the labor of research, however, was greatly improved and expedited by the enthusiastic and tireless contributions of a graduate student in the IU School of Library and Information Science, Ms. Noemi Rivera-Morales. Her contributions strengthened the paper throughout and allowed the author to meet the generously extended deadlines for completion.

1. William Belanger, U.S. Compliance with the Berne Convention, 3 Geo. MASON L. Rev. 373, 373 (1995) (noting that changes in global trade have led to international protections for intellectual property).

2. See, e.g., Ysolde Gendreau, Copyright Harmonization in the European Union and in North America, 20 Colum.-VLA J.L. \& ARTS 37 (1995); David Nimmer, Nation, Duration, Violation, Harmonization: An International Copyright Proposal for the United States, 55 LAW \& CONTEMP. PROBS. 2, Spring 1992, at 211. Harmonization has also been important in an era of multinational computer networks and instant communication and business transactions. Neil Weinstock Netanel, Asserting Copyright's Democratic Principles in the Global Arena, 51. VAND. L. REV. 217, 312-13 (1998). 
However, this harmonization also has brought distinct change to U.S. law in ways contrary to the fundamental purposes of copyright law and its social objectives.

The influence of harmonization in reshaping U.S. copyright law has been evident for decades. Beginning with the Copyright Act of $1976^{3}$ and continuing through a series of amending statutes, several fundamental changes in the law result directly from the press for harmonization. ${ }^{4}$ This transition is often manifest in compliance with multinational treaties. ${ }^{5}$ For example, the United States joined the Berne Convention for the Protection of Literary and Artistic Works $^{6}$ in 1989, which mandated several changes. ${ }^{7}$ An unwillingness to adopt those changes was one major reason for the United States's long delay in becoming a signatory to that treaty. ${ }^{8}$ Congress anticipated that the United States eventually would join the treaty and began to make some of the required changes with the passage of the Copyright Act of 1976. ${ }^{9}$ Congress took additional and theoretically "final" steps toward treaty compliance with amendments to the 1976 Act in 1988 and $1990 .^{10}$ Yet, pressure for additional change continues. Some member countries have argued that the United States has not fully conformed to the requirements of the Berne Convention, and in the meantime, more recent treaties have compelled further restructuring of U.S.

3. Copyright Act of 1976, Pub. L. No. 94-553, 90 Stat. 2541

4. Although the actual statutory changes of importance in this Article began with the Copyright Act of 1976, international developments had been deployed long before to argue for revisions in U.S. law. See, e.g., James J. Guinan, Jr., Duration of Copyright, Study No. 30, Copyright Law Revision, Sen. Comm. on the Judiciary, 86th Cong. (1961), at 62-70 (examining efforts in Congress, beginning in 1922, to revise U.S. law to conform with requirements of the Berne Convention).

5. See, e.g., World Intellectual Property Organization Copyright Treaty, Dec. 20, 1996, 36 I.L.M. 65 (1997) [hereinafter WIPO Copyright Treaty]; World Intellectual Property Organization Performances and Phonograms Treaty, Dec. 20, 1996, 36 I.L.M. 76 (1997) [hereineafter WIPO Performances and Phonograms Treaty]. For a general discussion of the WIPO Performances and Phonograms Treaty, see Rebecca F. Marin, The WIPO Performances and Phonograms Treaty: Will the U.S. Whistle a New Tune? 44 J. COPYRIGHT SOC'Y U.S.A. 157 (1997).

6. Berne Convention for the Protection of Literary and Artistic Works, Sept. 9, 1886, revised Paris, July 24, 1971, 25 U.S.T. 1341, 828 U.N.T.S. 221 [hereinafter Berne Convention]. The Berne Convention is a multinational treaty, with 130 signatory countries as of May 1998. See U.S. Copyright Office, INTERNATIONAL COPYRIGHT RELATIONS OF THE UNITED STATES, Circular 38a (1998). It fundamentally provides for mutual protection of copyrighted works in each country and sets substantive standards that the laws of each country must meet.

7. Berne Convention Implementation Act of 1988, Pub. L. No. 100-568, 102 Stat. 2853.

8. Belanger, supra note 1 , at 375 .

9. See supra text accompanying notes $3-4$.

10. See Berne Convention Implementation Act of 1988, Pub. L. No. 100-568, 102 Stat. 2853. See also Visual Artists Rights Act of 1990, Pub. L. No. 101-650, 104 Stat. 5089. 
copyright law."

\section{I. "HARMONIZATION" AND THE REVISION OF U.S. LAW}

Numerous examples of change in U.S. law are attributable to harmonization. The pressure for international conformity has altered the means for acquiring copyright, has restructured the term of copyright duration, and has brought new protection under U.S. law where no legal rights previously existed. The process of defining the conditions of harmonization also has generated some awkward results. New forms of protection sometimes extend only to certain works and apply only in narrow and ill-defined contexts. The quest for international harmonization has resulted in greater protection under U.S. law for foreign works than for domestic works. The transition from previous law to "harmonized" law has generated clumsy juxtapositions of legal doctrines, reflecting a collision of cultural and economic objectives that underlie copyright. Most of all, the drive toward greater harmonization has produced copyright law that simply drifts from its constitutional purposes, often generating results that are more complicated and at times divergent from the ideal of an international standard. ${ }^{12}$

\section{A. Restructured Term of Copyright Protection}

With the passage of the 1976 Act, Congress altered the term of protection for copyrighted works from a term of twenty-eight years, renewable for twentyeight additional years, ${ }^{13}$ to a term of life of the author, plus fifty years. ${ }^{14}$ Statistically, the "life-plus-fifty" term was not significantly longer than the prescribed term of seventy-five years under the previous law. ${ }^{15}$ Thus, the revision in 1976 did not greatly alter the average length of a copyright's

11. A principal treaty leading to most recent pressure for statutory change is the WIPOCopyright Treaty. See WIPOCopyright Treaty, supra note 5. For a discussion of some of the Treaty's implications, see infra text accompanying notes 74-77.

12. Belanger, supra note 1 , at 390 (arguing that the expanded scope of rights required under the Berne Convention exceeds "that necessary to promote the public dissemination of private works").

13. Copyright Act of 1909,17 U.S.C. $\$ 24$ (1976) (current version at 17 U.S.C. $\S 302$ (a) (1998))

14. Copyright Act of 1976, 17 U.S.C. $\$ 302$ (a) (1998). More recently, Congress extended that protection to the life of the author, plus seventy years. For a discussion of that development, see infra notes 78-82 and accompanying text.

15. James J. Guinan, Jr., Duration of Copyright, Study No. 30, Copyright Law Revision, Sen. Comm. on the Judiciary, 86th Cong. (1961), at 76 (referring to a 1930 study that protection for "life-plus-fifty" would result in an average term of protection of between 76 and 86 years). 
duration. The restructuring of the term was, however, a direct result of the Berne Convention that the United States was preparing to join in $1976 .{ }^{16}$ More importantly, the 1976 law brought a new term of copyright that would assure protection for the author's life, as well as for the subsequent generation. Under the previous Copyright Act of 1909, protection in the United States had been for an initial term of twenty-eight years plus a renewal for twenty-eight, not forty-seven, additional years. ${ }^{17}$ In 1962 , Congress began an incremental process of "ad interim" protection, eventually extending copyright for existing works to a term of twenty-eight plus forty-seven years. ${ }^{18}$ Congress specifically instituted that change to create a term of protection roughly equivalent to the number of years that one would have under a "life-plus-fifty" system.

The relative merit of basing copyright duration on a defined, albeit unrenewable, term versus a term determined by an author's life, is a policy question open to continued debate. ${ }^{19}$ Arguments for a term based on the author's life clearly have had the greatest influence on copyright laws around the world. In making the transition away from a fixed term, the United States generally applied the "life-plus-fifty" rule only to works coming into existence on or after January 1, 1978, and retained the fixed term for most other existing copyrights. ${ }^{20}$ Consequently, pre-1978 publications are generally protected for a maximum of seventy-five years; later works are protected for life-plus-fifty. ${ }^{21}$ Congress was not prepared to alter fundamentally the duration of existing copyrights. ${ }^{22}$ As a result, U.S. copyright law today embodies both systems for

16. In particular, the 1976 Act added new $\S \S 302-304$ related to the term of protection. Copyright Act of 1976, Pub. L. No. 94-553, 90 Stat. 2541

17. Copyright Act of 1909, 17 U.S.C. $\$ 24$ (1946).

18. The first step in this process was a 1962 enactment that extended existing copyrights until the end of 1965. Congress continued to renew those copyrights every 1 or 2 years. Until enactment of the Copyright Act of 1976. See, e.g., Pub. L. No. 87-668, 76 Stat. 555 (1962).

19. Author Samuel Clemens made an impassioned plea for copyright that should last at least for the author's life and some ensuing years. He testified before Congress in 1906 about the agony of living long enough to see some of his early works lapse into the public domain and of the desire to provide for his offspring. See Margolit Fox, The Rights of Writers as a Twain Obsession in a Rediscovered Manuscript; Wisdom Seeker and Statesman Spar, N.Y. TIMES, Feb. 16, 1998, at E1.

20. Copyright Act of 1976, 17 U.S.C. $\$ 304$ (1994). Although U.S. law was revised in 1976, the new law did not take effect until January 1,1978 . Hence, that date is pivotal in reference to significant changes in copyright standards. Pub. L. No. 94-553, $§ 102,90$ Stat. 2541, 2598-99 (1976).

21. This statement can only be made generally. Consistent with the Berne Convention, a fixed term of protection applies to works made for hire. In the United States, the term of protection is either 95 years from the date of publication or 120 years from creation, whichever occurs first. Copyright Term Extension Act, Pub. L. No. 105-298, § 102(b), 112 Stat. 2827 (1998) (amending 17 U.S.C. $\$ 302$ (c) (1994)).

22. Restructuring existing copyrights by converting them from a fixed term to a term based on the author's life could in many instances have disruptive effects on existing agreements for the exploitation of the works. 
measuring the term of copyright protection.

The effort to eliminate confusion by establishing an international standard instead has complicated the standard even further in the United States. To calculate the length of a copyright in the United States, one must first determine whether the work was created before or after January 1, 1978, a potentially difficult task. ${ }^{23}$ Furthermore, the revision of U.S. copyright in 1976 restructured the term of protection for existing unpublished works. ${ }^{24}$ The 1976 Act preempted the common-law copyright that previously had given unpublished works perpetual copyright protection as long as they remained unpublished. The pre-1978 protection of up to seventy-five years applied to the work only upon its publication.

Congress, in 1976, replaced the common-law rule with protection for unpublished works based on the life of the author, plus fifty years. Thus, unpublished works created before 1978 are protected for a term dependent on the author's life, while works published before 1978 are under copyright for the maximum fixed term of seventy-five years. Determining the duration of copyright thus requires identifying whether the work ever has been published. ${ }^{25}$ The quest for copyright information depends on an increasing array of facts,

For example, in the mid-1970s a purchaser of a copyright may have forecast investments in the work based on an expectation of at least 75 years of protection. A conversion to a term based on the author's life could shorten the duration, if the author should die shortly after creating the work. Similarly, the author may have negotiated a price for the copyright based on an expectation of 75 years of rights, but if the author lives longer than 25 years, the author may have underestimated the price. On the other hand, Congress has extended the term of protection on various occasions, notably after 1962 when duration was effectively extended from 56 to 75 years. See supra note 18. To adjust for that wind fall of continued protection, Congress gave to the original copyright owner, or heirs, a right to terminate the transfer of the copyright. Thus, an early transfer of the copyright based on an assumption of 56 years of protection could still be limited to last only 56 years. Copyright Act of 1976, 17 U.S.C. $\$ 304(c)$ (1994). Congress could possibly have alleviated some of the concerns about converting the duration of the existing copyright by providing a similar termination right and a minimum term of 75 years for existing copyrights. A second type of conflict with restructuring the duration of existing copyrights is a constitutional restriction. The Fifth Amendment to the U.S. Constitution stipulates: "nor shall private property be taken for public use, without just compensation." U.S. CONST. amend. V. Any redefinition of copyright's protection that could result in a shortening of existing duration could be construed as a violation of the "takings clause" of the Fifth Amendment. Again, assurance of at least 75 years for pre-1978 works may have avoided that pitfall.

23. U.S. COPYRIGHT OFFICE, HOW TO INVESTIGATE THE COPYRIGHT STATUS OF A WORK, Circular 22, at 7 (1995).

24. See Copyright Act of 1976, 17 U.S.C. $\$ 303($ a) (1994)

25 . It is actually even more complex than this brief summary suggests. In the case of pre-1978 unpublished works, for example, protection continues through December 31,2002 , regardless of the date of the author's death. Further, if the work is published before December 31, 2002, copyright continues for at least an additional 45 years through December 31, 2047. Copyright Term Extension Act, Pub. L. No. 105-298, § 102(c), 112 Stat. 2827 (1998) (amending 17 U.S.C. $§ 303$ (a) (1994)). 
many of which are difficult or impossible to isolate. Those facts may include the place of creation of the work, ${ }^{26}$ the date of creation, ${ }^{27}$ the date of publication, ${ }^{28}$ whether it is a work made for hire, ${ }^{29}$ and the date of the author's death. ${ }^{30}$ One must also determine whether an apparently unpublished document in fact has been published at any time and in any form. ${ }^{31}$ Discovering those basic facts can require extensive research. ${ }^{32}$

The restructured term of copyright protection is an essential part of the harmonization of copyright, and it is designed to make the law consistent and more predictable. But the restructured term has not meshed well with U.S. law, leaving the duration of copyright protection under U.S. law distinctly "unharmonized" and vastly more complex. The complexity of a dual system of duration may continue under existing law as long as copyrights vested before 1978 exist. Since most of those copyrights previously lasted for seventy-five years, the dual system was extended to last until 2053, seventy-five years after 1978. ${ }^{33}$ This Article will later examine the recent successful effort to extend copyright by twenty years. ${ }^{34}$ Because the extension has become law, the "temporary" transition will now last until at least 2073.

26. If the work originated in a country that is not a party to the Berne Convention or another treaty, it may have no copyright protection in other countries. See Copyright Act of 1976, 17 U.S.C. $\S 104$ (1994).

27. As already analyzed, the term of protection under U.S. law differs, depending on whether the work was created before or after January 1, 1978. See supra text accompanying notes 21-22.

28. Under pre-1978 law, the fixed term of protection began only upon publication. Further, if a work was created before 1978, but published after the effective date of the new law, the work may receive the additional forty-five years of protection. See Copyright Term Extension Act. Pub. L. No. 105-298, § 102(c), 112 Stat. 2827 (1998) (amending 17 U.S.C. $\$ 303(a)$ (1994)).

29. A "work made for hire" is, in general, a work created by an employee within the scope of employment. Copyright Act of 1976, 17 U.S.C. $\$ 101$ (1994). In that event, the copyright belongs to the employer, and the term of protection is either ninety-five years from the date of publication or 120 years from the date of creation, whichever occurs first. Copyright Term Extension Act, Pub. L. No. 105-298, § 102(b), 112 Stat. 2827(1998) (amending 17 U.S.C. $\$ 302$ (c) (1994)). Determining whether a work is one made for hire clearly provides for a term of protection that breaks from the general contemporary rule of "life-plus-fifty," or "life-plus-seventy" under the newly extended term.

30. If a copyright lasts for a period of years following the author's death, the author's basic obituary information becomes crucial.

31. For example, a researcher has possession in 1999 of a manuscript letter by an author who died in 1890. The copyright may not have expired, because the rule of life-plus-seventy for such works does not take effect until 2003. On the other hand, if the work had been properly published in 1900 , even if the researcher is not aware of that publication, the copyright expired at the latest in 1995. Another possibility is that the heirs published the letter in 1990. In that event, the copyright lasts until at least 2048. Researching these possibilities for publication is crucial for the scholar who may want to use that letter in a book or other work.

32. See U.S. COPYRIGHT OFFICE, supra note 23.

33. See Tung Tin, Reviving Fallen Copyrights: A Constitutional Analysis of Section 514 of the Uruguay Round Agreements Act of 1994, 17 LoY. L.A. ENT. L.J. 383, 383 (1997).

34. See infra text accompanying notes 78-82. 


\section{B. Limited Requirement of Copyright Formalities}

The requirement of executing certain formalities in order to secure protection, at least for published works, had been a long-standing fixture of U.S. copyright law before 1978 . Under pre-1978 law, those formalities were the inclusion of a copyright notice on published works and registration of the work with the U.S. Copyright Office..$^{35}$ These requirements were antithetical to the standards of the Berne Convention. ${ }^{36}$ With passage of the 1976 Act, Congress began phasing out the notice and registration requirements, ${ }^{37}$ ultimately eliminating them as requirements for copyright protection in 1989 when the United States joined the Berne Convention. ${ }^{38}$ Congress, however, did not eliminate entirely the benefits of formalities. ${ }^{39}$

Registration is often required before filing a copyright infringement lawsuit, although that registration can occur long after the work is created or even published; copyright protection still vests automatically. ${ }^{40}$ As a practical matter, registration is necessary for copyright owners because published works must still be deposited with the Library of Congress, ${ }^{41}$ and the process of depositing the work is little different from formal registration. If the copyright owner goes to the trouble of depositing the work, he is advised to register the work at the same time. Moreover, registration prior to an infringement provides the copyright owner with significant financial remedies in a successful infringement action. ${ }^{42}$ The copyright owner can ask the court for "statutory damages" in lieu of actual damages, ${ }^{43}$ and the copyright owner may, if successful, obtain attorneys' fees from the defendant. ${ }^{44}$ In many cases, the inability to secure statutory damages and reimbursement of attorneys' fees means that a copyright infringement action is economically impossible to

35. Copyright Act of 1909, 17 U.S.C. $\$ \S 9-10$ (1946). The 1909 Copyright Act did not specifically require registration of published works, but the copyright owner did need to deposit two copies of the work with the Library of Congress at the time of publication and file a renewal registration 28 years later. For all practical purposes, these requirements made registration an expected step at the time of publication. See Nimmer, supra note 2 , at 219 n.54.

36. See MARShall LeafFer, UNDERStaNdING Copyright LaW, 380-81 (2d ed. 1995).

37. See Copyright Act of 1976, Pub. L. No. 94-553, 90 Stat. 2541, 2576-83.

38. See Berne Convention, supra note 7.

39. Belanger, supra note 1, at 394-95 (arguing that continued requirement of formalities for certain remedies nevertheless complies with the Berne Convention).

40. Copyright Act of 1976, 17 U.S.C. § 411 (a) (1994).

41. Id. $\$ 407$.

42. Id. $\$ 412$.

43. Id. $\$ 504$.

44. Id. $\$ 505$. 
prosecute. ${ }^{45}$ Some critics object that the United States has not fully complied with the treaty ${ }^{46}$ because it has made the formalities of notice and registration a precondition to the practical ability to enforce a copyright. ${ }^{47}$

\section{Restoration of Foreign Copyrights}

While the United States took the most recent step to eliminate the notice and registration formalities in $1989,{ }^{48}$ many other countries long had been signatories to Berne and had dropped formalities decades before. ${ }^{49}$ Consequently, for example, a French author had not been required to comply with formalities to obtain protection in France and in many other countries that already had eliminated the prerequisites. However, once that work had been exported to the United States, the work entered the public domain in the United States if it lacked a copyright notice and perhaps registration. ${ }^{50}$ The works of many unsuspecting foreign authors entered the public domain during the

45. A good example of the importance of recovering attorney fees is Basic Books, Inc. v. Kinko's Graphics Corp., 758 F.Supp. 1522 (S.D.N.Y. 1991). The court held that the commercial photocopy shop infringed the copyrights held by book publishers when it photocopied and sold "course packs" comprising chapters from various books. Basic Books, Inc. v. Kinko's Graphics Corp., 1991 U.S. Dist. LEXIS 19930 (S.D.N.Y. Oct. 16, 1991). The court awarded the publishers statutory damages in the amount of $\$ 510,000$, and Kinko's was required to reimburse the publishers' attorney fees in the amount of $\$ 1,365,000$. Id. Clearly attorney fees can vastly outstrip damages, and the ability to recover them can determine the feasibility of legal action. In 1994, the U.S. Supreme Court ruled that either a plaintiff or a defendant may be a "prevailing party" in an infringement lawsuit and thus allowed under the Copyright Act of 1976, 17 U.S.C. $\$ 505$ (1994), to request an award of attorney fees. Fogerty v. Fantasy Music, 510 U.S. 517, 534 (1994). Timely registration, however, is a prerequisite to the ability of the copyright owner, not the defendant, to receive this remedy. Copyright Act of 1976, 17 U.S.C. $\$ 412$ (1994).

46. For critical examinations of current formality requirements under U.S. law, see Irwin Karp, A Future Without Formalities, 13 CARDOzo ARTS \& ENT. L.J. 521 (1995); Shira Perlmutter, Freeing Copyright from Formalities, 13 CARDOZO ARTS \& ENT. L.J. 565 (1995).

47. To relieve some critics, the requirement of registration before filing a lawsuit does not apply to most foreign works. Copyright Act of 1976, 17 U.S.C. $\$ 411$ (a) (1994). On the other hand, registration as a precondition to statutory damages and attorney fees does not change the fact that the copyright owner has enforceable rights. John B. Koegel, Bamboozlement: The Repeal of Copyright Registration Incentives, 13 CARDOZO ARTS \& ENT. L.J. 529, 535 n.33 (1995). Moreover, the previous common-law protection for unpublished works did not allow recovery of either statutory damages or attorney fees, so registration actually allows an expansion of rights that did not exist before the effective date of the Copyright Act of 1976. Id. at 530 n. 10 .

48. See Berne Convention, supra note 6.

49. See U.S. Copyright OfFice, INTERnational Copyright Relations of the UnItEd States, Circular 38a (1998), for a list of countries adhering to the Berne Convention, with their dates of accession. See Nimmer, supra note 2, at 228-32 (discussing the conflicts of copyright protection that arose during the era when U.S. law continued to require formalities)

50. See supra note 35 and accompanying text. 
decades the United States held fast to formalities. In a striking development that began with the North American Free Trade Agreement (NAFTA), ${ }^{\text {st }}$ and was later expanded by the General Agreement on Tariffs and Trade (GATT),${ }^{52}$ the United States was obligated to bring many of those foreign copyrighted works that had entered the public domain back under copyright protection..$^{53}$

Effective January 1, 1996, U.S. copyright protection was restored to a broad range of materials that originated in other countries but, due to noncompliance with U.S. formalities, had lost protection in the United States. ${ }^{54}$ The copyright was restored for the remaining term of protection that the works would otherwise have enjoyed, which was typically a period of seventy-five years from the date of original publication. ${ }^{\text {s5 }}$ Foreign works that were once in the public domain are now back under copyright. However, U.S. works that also entered the public domain due to inadequate formalities had to remain in the public domain. As a result, U.S. law gives stronger copyright protection to a broader class of foreign works than it gives to similar domestic works. U.S. law also demands that a researcher identify whether or not the work originated in the United States in order to determine whether it may still be protected. Often that seemingly simple information can be extraordinarily difficult to ascertain.

D. Moral Rights

Moral rights for authors and artists are a European concep $\mathrm{t}^{56}$ introduced

51. North American Free Trade Agreement, Dec. 17, 1992, U.S.-Can.-Mex., 32 I.L.M. 289 (1993), 32 I.L.M. 605 (1993) [hereinafter NAFTA].

52. General Agreement on Tariffs and Trade, General Agreement on Tariffs and Trade, Oct. 30, 1947, 61 Stat. 1103, 55 U.N.T.S. 187 [hereinafter GATT].

53. Before the current version of 17 U.S.C. $\S 104 A$, Congress enacted a statute in 1993 pursuant to NAFTA that had a relatively limited application to motion pictures. See North American Free Trade Agreement Implementation Act, Pub. L. No. 103-182, 107 Stat. 2057, 2115 (1993). The current statute applies more broadly to all types of works, as required by GATT. See Uruguay Round Agreements Act, Pub. L. No. $103-465,108$ Stat. 4809,4976 (1994). Even before entering into these treaties, the United States arguably was required to grant retroactive protection to some foreign works under the Berne Convention. Congress apparently intended not to accept retroactive protection, although it apparently changed that policy in more recent years. See Nimmer, supra note 2, at 229.

54. Copyright Act of 1976, 17 U.S.C. § 104(A) (1998).

55. Ironically, the protection for 75 years is still not true "harmonization." Many other countries long ago adopted a "life-plus-fifty" rule, while in the United States the work is restored to a fixed duration.

56. Arthur B. Sackler, The United States Should not Adhere to the Berne Copyright Convention, 3 J.L. \& TECH. 207, 209 (1988). "The concept of moral rights . . . has long been recognized in European and other countries." Belanger, supra note 1, at 383 . 
into U.S. copyright law in a most minimalistic manner solely to comply with Berne Convention obligations. ${ }^{57}$ Moral rights in the United States give an artist of certain "works of visual arts"s8 the right to preserve his or her name on copies of works, ${ }^{59}$ as well as the right to have the artist's name removed if an owner of the copy alters it in ways objectionable to the artist. ${ }^{60}$ Moral rights also give artists of certain works the ability to prevent the owner of the copy from destroying it. ${ }^{61}$ Authors and artists in the United States did not have these rights before the enactment of moral rights provisions in $1990 .^{62}$ The result has been a distinct expansion of the scope of rights, at least for a narrow class of works.

\section{E. Bootleg Sound Recordings}

While moral rights were a new form of right for some copyrighted works, treaty requirements also extended U.S. legal protection to works that previously lacked copyright protection altogether. The lack of legal protection for bootleg recordings of musical performances is a surprising void, making this revision perhaps the most sympathetic of all changes in U.S. law described in this Article. An unauthorized sound recording of a performance, due to a quirk in U.S. copyright law and constitutional interpretation, had previously lacked copyright protection for the performer. The person making the recording was not responsible for the original performance captured on tape, and thus had contributed no "originality" to the work. The performer had not authorized the recording and consequently was not the one "fixing" the performance onto the

57. Belanger, supra note 1 , at 383.

58. Copyright Act of 1976, 17 U.S.C. $\S 101(1998)$ (defining "work of visual art").

59. Id. $\S 106 \mathrm{~A}$ (a) (explaining the right of paternity or attribution).

60. Id.

61. Id.; See Martin v. Indianapolis, 982 F.Supp. 625 (S.D. Ind. 1997), for a leading case on this issue.

62. Belanger, supra note 1, at 399 (noting that moral rights are the "most significant" area in which the United States continues to fail to meet the requirements of the Berne Convention). 
tape.$^{63}$ Hence, that recording was not the work of the performer or the recorder. Protection for such a sound recording often fell into a legal void. The existence of that void was inconsistent with the laws of most other countries and with multinational treaty requirements. ${ }^{64}$

The United States now provides legal protection for the performers, giving them the ability to bring action against persons who make and distribute bootleg recordings. ${ }^{65}$ However, that protection is not "copyright" law. Rather, it is protection enacted by Congress under either its commerce or treaty powers ${ }^{66}$ but it applies the remedies given to a copyright owner under the Copyright Act. ${ }^{67}$ It is for all practical purposes copyright protection for unauthorized sound recordings, but enacted by Congress under its other powers found in the U.S. Constitution, thereby avoiding the rigors of the Copyright Clause..$^{68}$

\section{F. Database Protection}

The World Intellectual Property Organization (WIPO) Copyright Treaty of 1996 provides that databases shall be protected ${ }^{69}$ a declaration that, in many applications, defies established U.S. copyright law. In 1991, the U.S. Supreme

63. Copyright Act of 1976, 17 U.S.C. $\$ 101$ (1998). The definition of "fixed" provides that a work eligible for copyright must be fixed "by or under the authority of the author." $I d$. A bootleg recording is not made with the authority of the copyright owner of the composition or the performer. The U.S. Constitution empowers Congress to grant protection only to "authors" for "their writings." U.S. CoNST. art. I, \& 8, cl. 8. The power may not encompass "writings" that are "fixed" by someone other than the "author." 17 U.S.C. $\$ 101$. The issue of bootleg recordings deals largely with the interests of the performer of a musical composition. If the composition existed in a "fixed" version, whether as a musical score or as a separate recording, before the performance that was "bootlegged," the composer most certainly has copyright protection for the composition. Hence, the composer could take action against many uses of the bootlegged recording, while the performer would not have any rights under previous law. The new statute gives rights to the performer. Copyright Act of 1976,17 U.S.C. $\$ 1101$ (1998).

64. See Peter Jaszi, Goodbye to All That: A Reluctant (and Perhaps Premature) Adieu to a Constitutionally-Grounded Discourse of Public Interest in Copyright Law, 29 VAND. J. TRANSNAT'L L. 595 (1996).

65. Copyright Act of 1976, 17 U.S.C. $\$ 1101$ (1998). One critic notes that because the anti-bootlegging statute is technically separate from the basic regime of copyright protection, it is not necessarily subject to the limited term of protection and offers "potentially perpetual protection." Jaszi, supra note 64, at 603.

66. U.S. CONST. art. I, $\S 8, \mathrm{cl} .3$ \& art. VI; Jaszi, supra note 64 , at 605 (referencing the Commerce Clause as the source of congressional power).

67. Copyright Act of 1976, 17 U.S.C. $\$ 110(a)$ (1998).

68. Jaszi, supra note 64 , at 602 . "While dealing with a creative activity, which has been acknowledged to represent a form of authorship, the anti-bootlegging provisions go beyond what Congress could do if it were legislating under the Patent and Copyright Clause." Id.

69. WIPO Copyright Treaty, supra note 5, art. 5. "Compilations of data or other material, in any form, which by reason of the selection or arrangement of their contents constitute intellectual creations, are protected as such." Id. 
Court ruled as a constitutional matter that copyright law could not protect compilations of data that were not selected, arranged, or coordinated in some original manner. ${ }^{70}$ The database in the $1991 \mathrm{case}$, an alphabetical telephone listing, was merely an unoriginal compilation of unprotectable facts, and it could have no copyright protection. ${ }^{17}$ Many other countries provide protection for such databases and saw the U.S. decision in Feist Publications, Inc. v. Rural Telephone Service Co., Inc. to be an anomaly that left many databases in the public domain. Such databases still lack protection in the United States, and U.S. copyright law cannot encompass them. ${ }^{72}$ In an exercise of congressional power to regulate interstate commerce, proposals in Congress would have extended sui generis legal rights for databases where copyright ends. ${ }^{73}$ Once again, treaty obligations have compelled the prospect of change in intellectual property law. In this instance, the change is potentially in direct contravention of a constitutional decision rendered by the U.S. Supreme Court.

\section{THE CONTINUING MARCH OF HARMONIZATION}

The march of harmonization continues with additional new legislation and further treaty negotiations. ${ }^{74}$ One direct example of this development is the right to secure "copyright management information" (CMI) and "copyright protection systems" (CPS) pursuant to the WIPO treaty. ${ }^{75}$ These additions to U.S. copyright law do not come without controversy. The statutes that now authorize copyright owners to place technological controls and to prescribe regulatory information in connection with the access to and dissemination of protected works also impose severe penalties on individuals who circumvent or remove the controls on that information. Those penalties would apply even if

70. Feist Publications, Inc. v. Rural Telephone Service Co., Inc., 499 U.S. 340 (1991).

71. According to the Supreme Court, the alphabetical telephone listing was a "garden variety" listing that lacked "some minimal degree of creativity." Id. at 362.

72. The Feist decision is based on a constitutional requirement for U.S. copyright protection, and hence an Act of Congress pursuant to the Copyright Clause cannot overturn it. See id. at 363-64.

73. Digital Millennium Copyright Act, H.R. 2281, 105th Cong., tit. 5 (1998) (Title 5 is entitled "Collections of Information Antipiracy Act"); Collections of Information Antipiracy Act, S. 2291, 105th Cong. (1998); See Jaszi, supra note 64, at 605 (questioning the constitutionality of the database legislation).

74. At least one piece of legislation from recent years, offered with the objective of treaty compliance, has died with little prospect for reintroduction. A bill in 1993 would have eliminated the requirement of registration as a precondition to filing a lawsuit and securing certain remedies. See supra notes $35-45$ and accompanying text. See Koegel, supra note 47 , for a critical examination of the bill.

75. WIPO Copyright Treaty, supra note 5, art. 11, 12; Digital Millennium Copyright Act, Pub. L. No. 105-304, § 103(a), 112 Stat. 2860, 2863-76 (1998) (to be codified at 17 U.S.C. Title 12). 
a user were to take actions in order to utilize the resources in a manner consistent with fair use or other legal rights to use copyrighted works. ${ }^{76}$ Thus, while the law explicitly states that the addition of CMI and CPS does not affect the exercise of fair use, copyright owners may unilaterally impose regulatory devices that could restrict uses more narrowly than would be within the framework of existing fair use, exposing a user to legal liability for bypassing CMI or CPS in pursuit of the lawful exercise of fair use. ${ }^{77}$ Fair use may continue to apply to works once they are lawfully accessed, but the copyrighted works will, as a practical matter, be locked behind secured devices and software blocks. Access may also be limited by contractual obligations that could limit fair use.

Another development in U.S. law is the recent, successful effort to extend the term of copyright protection. The Copyright Term Extension Act adds twenty years of protection to the current copyright duration provided under the law. ${ }^{78}$ This new law extends that term to life of the author plus seventy years. The bill would add twenty years to almost all works, including works made for hire and unpublished manuscripts originating before 1978.

The impetus for this development grows largely out of a similar extension of the term adopted by many countries. ${ }^{79}$ The term of "life-plus-seventy" has been advanced as the appropriate standard for all members of the European Union. ${ }^{80}$ This change in U.S. law is not required under any treaty or other obligation on the part of the United States. It is simply an effort to "harmonize up" with the laws of other countries in order to provide maximum protection for U.S. copyrights in those other countries. It is also a tremendous windfall of twenty additional years of protection for all new works, particularly for existing

76. Considerable controversy about the survival of fair use surrounds the new law. The law does include provisions that explicitly provide for the preservation of fair use, but it does allow restrictions on access to copyrighted works, even if that access is for lawful purposes, such as fair use. See Digital Millennium Copyright Act, Pub. L. No. 105-304, § 103(a), 112 Stat. 2860 (1998) (to be codified at 17 U.S.C. Title 12).

77. The bill as passed by Congress does include provisions that ostensibly preserve fair use. See, e.g., Digital Millennium Copyright Act, Pub. L. No. 105-304, § 103(a), 112 Stat. 2860 (1998) (to be codified at 17 U.S.C. Title 12).

78. Copyright Term Extension Act, Pub. L. No. 105-298, 112 Stat. 2827 (1998).

79. See Lisa M. Brownlee, Recent Changes in the Duration of Copyright in the United States and European Union: Procedure and Policy, 6 FORDHAM INTELL. PrOP. MEDIA \& ENT. L.J. 579 (1996); Shauna Bryce, Life Plus Seventy: The Extension of Copyright Terms in the European Union and Proposed Legislation in the United States, 37 HARV. INT'L L.J. 525 (1996); Jerome N. Epping, Harmonizing the United States and European Community Copyright Terms: Needed Adjustment or Money for Nothing, $65 \mathrm{U}$. CIN. L. REV. 183 (1996).

80. Directive on Harmonizing the Term of Protection of Copyright and Certain Related Rights, Council Directive 93/98, 1993 O.J. (L290/9). 
U.S. works that may otherwise have been on the verge of entering the public domain. $^{81}$

These developments, often in the name of harmonization, are supported by some compelling arguments. Indeed, the arguments in favor of change have been sufficiently persuasive in the negotiation of treaties, the ratification of treaties by the U.S. Senate, the enactment of amendments to the Copyright Act by both the House and the Senate of the U.S. Congress, and the signing of those bills into law by the President of the United States. Passage by Congress of the latest bills, designed to implement the WIPO Treaties and extend the term of copyright, are merely the latest evidence of the pressure for harmonization.

Arguments in favor of passage center largely on economic implications. ${ }^{82}$ For example, the extended term of protection may generate twenty more years of commercial revenue for many economically viable works. Much of that revenue may come from foreign countries where many novels, motion pictures, and other U.S. works from the early twentieth century continue to find a market. The economic argument translates not only into greater revenues for U.S. copyright holders, but also into the subsequent tax revenues, employment prospects, and shareholder profits that accompany expanded business. Moreover, if those revenues are derived from foreign markets, the strengthened protection and longer term of protection for copyrights may also help shift the balance of international trade in favor of the United States.

Many of the arguments in favor of these changes also exacerbate tensions among property claims, the rights of creators, and the public rights of use. For example, one basic principle of copyright is the separation of the work from its copyright. $^{83}$ An artist, for example, may create and sell a painting. Unless otherwise agreed, the buyer owns only the object; the copyright and its appurtenant privileges remain with the artist. One outgrowth of this legal construct is that the buyer has property rights with respect to the painting and may treat the physical object in almost any manner chosen, including further resale or even destruction of the work, whether the work is a painting, book, videotape, or other copyrighted work. However ill-advised destruction may be,

81. Indeed, concerns about imminent expiration of some major works from the 1920 s and 1930 s have motivated the Gershwin estate and the Disney companies to be major proponents of term extension. Steve Zeitlin, Editorial, Strangling Culture with a Copyright Law, N.Y.TIMES, Apr. 25, 1998, at A15.

82. One strong critic of term extension presented his arguments at hearings before the U.S. Senate Judiciary Committee and lamented that his points were overwhelmed by the more immediate concern of lost revenue that could result if copyrights were not granted the additional 20 years. See Jaszi, supra note 64 , at 598.

83. Copyright Act of 1976, 17 U.S.C. § 202 (1998). 
it is consistent with traditions of property ownership. Burning a book may carry historical or social stigma, but it is the right of the book owner. ${ }^{84}$ The granting of moral rights, however, conflicts with those traditions of private property. One may still burn or discard a book, regardless of its value or uniqueness, but if the owner of a "work of visual art" sends that work to its demise, the owner may face damage claims payable to the artist. ${ }^{85}$ Perhaps more pragmatic for modern industry, a representative of a major publishing company argued strongly against adoption of moral rights in U.S. law because of its potential interference with the ability of publishers to crop photographs and edit writing. ${ }^{86}$ While the version of moral rights eventually adopted in the United States extends only to certain works of "visual arts," this layer of rights belongs to artists and other creators of new works. Therefore, even if the editor properly obtains consent from the copyright owner, the moral rights nevertheless may well belong to yet another party. Editors, publishers, and others would need to redouble their efforts by obtaining clearances from both the copyright owner and the original artist. ${ }^{87}$

84. This writer is hardly an enthusiastic supporter of burning books, and indeed has been an active proponent of the preservation of historical materials. One might also argue that a limitation on the right to destroy a copyrighted work may be consistent with efforts to preserve historical buildings and other architectural sites. Often when a site is identified for historical preservation, the owner is prevented by law from destroying or altering the building. The social objectives of such law are laudable. On the other hand, historical preservation is fundamentally different from moral rights. For example, moral rights are legal rights that belong only to the individual creator, while rights to prevent destruction of historical buildings are enforceable by governmental authorities. Further, moral rights, at least in the United States, last only for the life of the artist, while preservation restrictions last indefinitely. Consequently, preservation restrictions may in fact limit free exercise of property rights. Penn Central Transportation Co. v. New York City, 438 U.S. 104 (1978) (upholding the constitutionality of preservation laws). However, they do so in a manner that is more clearly directed at serving a broader public objective, rather than a personal one.

85. Copyright Act of 1976,17 U.S.C. $\S 106$ A (1998).

86. Sackler, supra note 56 , at 207-08.

87. Ironically, one major argument against adoption of moral rights was that it would require additional

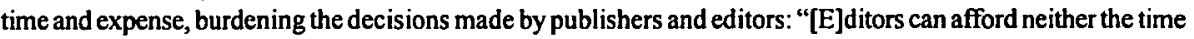
to obtain consent for specific uses of works nor to hesitate on decisions out of concern that they may subsequently be second-guessed in litigation." Sackler, supra note 56, at 208. See also Roberta Rosenthal Kwall, How Fine Art Fares Post VARA, 1 MARQ. INTELl. Prop. L. REv. 1, 3 (1997) ("When the United States joined Berne in 1988, the entertainment and publishing industries vehemently opposed the adoption of specific moral rights legislation."). Publishers have strongly rejected similar arguments from educators and librarians seeking to make "fair use" of existing publications. See, e.g., Carol Risher, Libraries, Copyright and the Electronic Environment (Barcelona, Apr. 1996) (position paper on behalf of the International Publishers Copyright Council of the IPA $25^{\text {th }}$ Congress, on file with the Copyright Management Center at Indiana University-Purdue University Indianapolis). The Sackler article also objects to the need to give attribution to the creators in addition to the copyright owner. Sackler, supra note 56, at 208. Again, publishers generally have insisted that educators and librarians include formal notices on any "fair use" copies, even though nothing in the "fair use" law requires attribution. 
Other changes in copyright law in the name of "harmonization" also defy deeper principles of property ownership. Rights of free alienation are generally secured by the "first-sale" doctrine of copyright law ${ }^{88}$ which allows the owner of a lawful copy to pass that copy to others by sale, gift, or rental. The WIPO Copyright Treaty of 1996, by contrast, calls for some curtailment of leasing certain works. ${ }^{89}$ This right to lend, lease, or transfer ownership of copies of protected works has not been unlimited under recent U.S. law. For example, in 1990 , Congress revised the "first-sale" statute ${ }^{90}$ to preclude the commercial rental or lending of computer programs or sound recordings of musical works. ${ }^{91}$ The WIPO treaty, however, could allow federal law to add further restrictions on sales, rentals, or even loans of books, videotapes, and other works.

\section{HARMONIZATION AND THE HARM TO PUBLIC INTEREST}

Despite the pragmatic and economic arguments in favor of recent developments in U.S. copyright law, many changes have provided benefits ultimately to only a small number of individuals at the expense of a large segment of the U.S. public. U.S. copyright law is built on a principle of social policy that attempts to find a balance between granting rights of ownership and control to copyright owners and tempering those rights with a number of exceptions or "limitations" reserved to the public to make socially constructive uses of copyrighted works under limited circumstances. ${ }^{92}$ That balance between private rights and social utility is critical to U.S. copyright law and is implicit in the social objectives of the law as provided in the constitutional clause empowering Congress to make copyright law: "The Congress shall have Power ... To promote the Progress of Science and useful Arts, by securing for limited times to Authors and Inventors the exclusive Right to their respective Writings and Discoveries. ${ }^{993}$ Congress has the power to grant rights to copyright owners, but only if the measure of rights granted is apportioned to serve the overall objective of advancing knowledge and learning. If the grant of rights is too

88. Copyright Act of 1976, 17 U.S.C. $\$ 109$ (1998).

89. WIPO Copyright Treaty, supra note 5, art. 7.

90. Copyright Act of 1976, 17 U.S.C. $\$ 109$ (1998).

91. Judicial Improvement Act of 1990, Pub. L. No. 101-650, 104 Stat. 5089, 5134-35 (codified as Computer Software Rental Amendments Act of 1990, 17 U.S.C. $\$ 109$ (b)(1)(A) (1998)).

92. Netanel, supra note 2, at 220. "[C]opyright's constitutive, democratic purpose is both a primary rationale for according authors proprietary rights in original expression and the proper standard for delimiting those rights." Id.

93. U.S. ConsT., art. I, \& 8, cl. 8. 
broad or too rigid, then the public's ability to utilize protected works and to build on and to learn from them is unduly constrained.

Few of the recent changes in U.S. copyright law that have added to the rights of the copyright owner include any measure of corresponding balance of rights for the public. ${ }^{94}$ One fundamental reason for that lack of balance may simply be that these changes reflect an effort to harmonize U.S. law with laws originating in foreign countries where copyright law is not rooted in the same social principles and the same quest for a balancing of rights. Many Western European countries have stronger rights of private property and copyright ownership along with fewer rights regarding fair use than have been customary in the United States. Harmonizing U.S. law with such legal traditions might result in developments lacking the balance of public interest that has been a hallmark of U.S. law.

A trend of harmonization that adds predominately to the rights of the copyright owners without a corresponding balance of public rights promises fundamental change in U.S. copyright law at a high cost to the public. First, any expansion of scope or duration of protection is, by necessity, a corresponding contraction of the public domain. Loss of the public domain, even a partial loss, is a loss of one of the few clear opportunities for a member of the public to build upon existing works and to expand upon the base of creative resources available in the marketplace. Sometimes that member of the public is an individual acting alone or is a business executive seeking maximum profits and in turn contributing to the broader economy. Novels, for example, on which the copyrights have expired, have become available to the public as inexpensive reprints, public television serials, and major Hollywood motion pictures. The public domain is a valuable resource for individuals seeking affordable access to works and for large companies seeking to profit by bringing those works to market either in their original forms or in new media. ${ }^{95}$

94. Even more distressing than the lack of any broad limitation for public benefit is the inclusion in the Copyright Term Extension Act, Pub. L. No. 105-298, 112 Stat. 2827 (1998), of an exemption for the public performance of music and other works in restaurants, tavems, and other business establishments. The wisdom or appropriateness of such an exemption is beyond the scope of this Article, and it is not a new concept. It expands upon an existing provision. See Copyright Act of 1976, 17 U.S.C. $§ 110(5)$ (1994). The distress, however, is found in the congressional justification for that exemption, with some members of Congress arguing that it provides the essential protection for the public interest to balance against the windfall for private parties that would come from the additional 20 years of copyright. 144 Cong. Rec. H1457 (daily ed. Mar. 25, 1998) (statement of Rep. Sensenbrenner). It is true that the existing $\$ 110$ of the Copyright Act presents a litany of important limitations on owner rights, but a benefit for one class of commercial uses is far from adequate to compensate for the strain on the public interest generated by term extension.

95. For example, the Disney Company, which strongly supports term extension, has benefitted greatly 
Second, the trend toward tightened copyright protection harms the public good by narrowing the exercise of fair use. ${ }^{96}$ Fair use is a crucial element of the U.S. copyright system that allows limited uses of protected works in furtherance of the constitutional objectives. Fair use is not free use, and it is not an unrestricted opportunity to exploit unwilling copyright owners. Some copyright owners do object to some claims of fair use. However, fair use is essential not only to the public seeking to build on existing works, but also for the creation of the next generation of many new copyright-protected works. If new legal structures constrict fair use, the public loses opportunities to benefit from intellectual works in many creative ways, and the next generation of copyright owners is inhibited from using a previous generation of material as a fresh foundation.

A third consequence is undue restriction on the deployment of new technologies. The success of many new technologies, from the photocopier to the Internet, depends on the ability to utilize copyright protected materials in ways that raise questions about the possibility of infringement. The photocopier can reproduce copyrighted works; the VCR can play videotapes; the Internet can transmit or distribute digital works. The availability of the technology is alone hardly justification for revising copyright laws to allow full utilization of all technology. However, the advance of technologies is crucial for economic and social progress. Many of the recent developments in photo reproduction, telecommunications, and computer networking are central to enhanced communications, greater efficiency of commercial activity, and the growth of major industries. Much of the domestic and international economy today depends on a successful application of these technologies for the growth of business and for the exploration of new commercial opportunities. Just as the motion picture and publishing industries might argue that stronger copyright protection can reinforce their businesses and have strong positive consequences for the economy, so could the computer and technology industries argue that greater opportunities for reproduction and transmission of copyrighted works can make new technologies more useful, more valuable, and consequently of

from the public domain. Disney's 1996 movie, The Hunchback of Notre Dame, to cite one example, is a motion picture based on an 1831 novel by Victor Hugo. Without the expiration of the original work, Disney would have canceled its project or have paid handsome royalties to the Hugo estate.

96. In furtherance of GATT the United States and numerous other countries entered into the Agreement on Trade-Related Aspects of Intellectual Property Rights, Apr. 15, 1994, 33 I.L.M. 1199 (also known as TRIPS), and established the World Trade Organization. TRIPS allows fair use and other exceptions to the rights of the copyright owners, but only under narrow circumstances, possibly invalidating some of the applications of fair use in recent U.S. court rulings. Netanel, supra note 2, at 309-10. 
greater importance to the economy.

A fourth consequence for the public, resulting from restrictions, is the diminished ability to share or disseminate protected works. If teachers are barred from using materials in the classroom, leaders are constrained from sharing materials at public functions, and cultural programs are prohibited from performing or otherwise making works available to an audience, then the public is simply denied exposure to creative works. That lack of exposure translates into a loss of learning opportunities and a curtailment of cultural progress. Those restrictions may arise from longer copyright protection, new forms of enforceable legal rights, imposition of binding technological controls on access, and automatic grants of copyright protection for all works, regardless of the author's intent. ${ }^{97}$

\section{CONCLUSION: HARMONIZATION AND THE FUTURE OF COPYRIGHT}

Change is inevitable in any area of the law. Changes allow the law to adapt to new social demands and expectations and enable the law to be responsive to contemporary forces, whether political or technological. Critical examinations of copyright law and periodic revisions are essential. The problem with many of the recent changes in U.S. copyright law is that they are motivated overwhelmingly by the pressure for harmonization with the laws of other countries, rather than by the belief that the changes will produce better law. Especially lost in the recent debates over copyright has been any focus on the public interest and the constitutional foundation of copyright: to advance the growth of knowledge and learning.

That shift from the constitutional foundation of copyright represents the most problematic consequence of harmonization. The U.S. Constitution empowers Congress to make copyright law within the context of a social objective: "[t]o promote the Progress of Science and useful Arts." Historically, that clause has compelled an evaluation of the effect of copyright law, as well as any revisions and interpretations, in light of a tension that is inherent in the struggle over rights to intellectual property: identifying the scope of rights that

97. Reduced need for registration of works jeopardizes the completeness and integrity of the registration records at the U.S. Copyright Office. See Koegel, supra note 47 at 538 . It could also undermine the system of legal deposit of materials for addition to the collection of the Library of Congress. See Kenneth D. Crews, Legal Deposit in Four Countries: Laws and Library Services, 80 L. LiBR. J. 551 (1988). Legal deposit under American law is today required by statute, separate from any requirement of registration. See Copyright Act of 1976,17 U.S.C. $§ 408$ (1994). 
ought to belong to the owner of the work, while tempering those rights to grant public rights of use in order to encourage productive uses of existing works. ${ }^{98}$ A prominent example of that tension, as addressed in recent years, is the Feist decision from the U.S. Supreme Court in 1991.99 In Feist, the Court held that standard white-pages telephone directories were not sufficiently creative to be eligible for copyright protection. In so holding, the Court also rejected the "sweat of the brow" doctrine that had emerged in some lower courts. By that rule, copyright would vest in a work if time, money, or energy were expended. The Justices recognized that rejection of the "sweat" doctrine would jeopardize copyright for numerous. works that are the product of investment but lack creativity. The Court made clear that while such a result may seem inequitable, it is crucial for serving the objectives of copyright.

Despite that strong endorsement from the Supreme Court for the constitutional objectives of copyright, Congress is taking steps toward enactment of database protection legislation that would provide protection for noncreative compilations of data that the $F$ eist decision found inappropriate for copyright and its appurtenant rights. ${ }^{100}$ While the Supreme Court focused on the social objectives of the law, Congress has taken deliberate steps to serve instead commercial interests.

Similarly, recent legislation in the name of harmonization would test the constitutional power of Congress to grant copyrights for "limited times" as the copyright term continues to expand from the original maximum of twenty-eight years to a term of seventy years beyond the life of the author. ${ }^{101}$ Congress has confronted the constitutional limits on protections for bootleg recordings with new legislation, and it has tested traditional doctrines of property rights by giving artists moral rights regarding some of their visual works.

These changes represent not only a shift in the philosophical foundation of copyright and related law, but also a shift in the constitutional foundation for congressional measures. Congress is adopting legislation that, in many

98. Jaszi, supra note 64, at 596 (waming that "constitutionally-grounded arguments for limitations on proprietary rights will become irrelevant in tomorrow's intellectual property debates").

99. See supra text accompanying notes $70-72$ for a discussion of Feist.

100. See supra text accompanying notes $69-73$ for a discussion of the database legislation.

101. See Dennis S. Karjala, Comment of U.S. Copyright Law Professors on the Copyright Office Term of Protection Study, 16 EUR. INTELL. PROP. REV. 531 (1994)(highly critical of extending the term of protection and contests its constitutionality); see also Joseph A. Lavigne, For Limited Times? Making Rich Kids Richer Via the Copyright Term Extension Act of 1996, 73 U. DET. MERCY L. REV. 311 (1996); J.H. Reichman, An Evaluation of the Copyright Term Extension Act of 1995: The Duration of Copyright and the Limits of Cultural Policy, 14 CARDozo ARTS \& ENT. L.J. 625 (1996). 
respects, functions similarly to copyright law, but it is instead relying on either the Treaty Clause or the Commerce Clause for authority. Under the Treaty Clause, Congress can enact legislation consistent with treaties entered into by the United States, but that legislation may not expand congressional authority to take action that would contradict the U.S. Constitution. ${ }^{102}$ Through the last several decades, the Commerce Clause has become an expansive source of congressional authority for enacting diverse legislation that concerns almost any activity affecting more than one state. ${ }^{103}$

By contrast, the Copyright Clause begins with a statement of policy: that copyright privileges should be shaped to duly encourage the creation of new works and to allow limited public uses also for the growth of knowledge. ${ }^{104}$ That policy has been interpreted as a dynamic force shaping copyright law and defining the boundaries of congressional development of copyright statutes. ${ }^{105}$ On the other hand, a database bill enacted under commerce powers would not be required to balance the rights of copyright owners and the rights of the public; the bill may grant protection to compilations of data that are constitutionally unprotected under copyright law. The bill may also allow protection of an indefinite duration, while copyrights are constitutionally allowed for "limited times." The bill recently in Congress had exactly those attributes.

These developments in the law reflect not only constitutional, policy, and philosophical shifts, but they also manifest a steady shift in the identity of the stakeholders in the shaping of U.S. intellectual property law. Copyright law protects works such as motion pictures and computer software, a growing source of domestic employment and revenue as well as foreign trade. The economic importance of movies, computer programs, and other works has been a powerful influence shaping U.S. copyright law. Computer technology has brought inexpensive and efficient means for reproducing and transmitting

102. See Reid v. Covert 354 U.S. 1 (1957). But cf. Missouri v. Holland, 252 U.S. 416 (1920) (treaties may establish law that conflicts with state authority).

103. See Heart of Atlanta Motel v. United States, 379 U.S. 241 (1964). See also United States v. Lopez 514 U.S. 549 (1995) (striking down federal legislation barring possession of a gun in the area around a school), for the isolated recent example of the Supreme Court finding that Congress has exceeded its authority under the Commerce Clause.

104. "[F]ull compliance with the Berne Convention would shift the balance of U.S. law, arguably placing an author's rights ahead of the public interest in access to copyrighted works, such compliance would be unconstitutional." Belanger, supra note 1 , at 391 .

105. Feist, 499 U.S. at 349 (noting that copyright law may produce some results that "seem unfair," but those results are sometimes a "constitutional requirement"). 
protected content to and from any location in the world. The strength of these industries in the current economy and the ease of committing infringements have combined to persuade most lawmakers of the need for considerably stronger protections for intellectual property. The strengthened rights, however, are often without a corresponding right of public use - whether that right is fair use or a clearer establishment of the public domain.

Thus, the economic pressures and the growing international significance of copyright have led to new law. That new law is overwhelmingly in furtherance of expanding protection, easier protection, and longer protection. Moral rights, database protection, technological controls, extended copyrights, eliminated formalities, and even restored copyrights that were long in the public domain are symptoms of a legal regime of extraordinary and rapid growth. That growth, however, has been the direct outcome of legislation reaching beyond the constitutional limits found in the Copyright Clause and underscored by the Supreme Court. Congress is also securing greatly strengthened legal rights without the constitutional policy to balance those rights for the benefit of the public. The public may well benefit from the economic residuals of legal strictures, but the public will ultimately lose as cultural and intellectual progress is increasingly subject to rigorous structures of the law. 